\title{
Health and Safety Challenges, and Perceptions of Private Sector Waste Operators in Lagos, Nigeria
}

\author{
Mynepalli K. C. Sridhar*, Mumuni Adejumo \\ Department of Environmental Health Sciences, Faculty of Public Health, College of Medicine, University of \\ Ibadan, Ibadan, Nigeria \\ Email: ${ }^{\text {mkcsridhar@gmail.com }}$
}

Received 24 December 2013; revised 30 January 2014; accepted 8 February 2014

Copyright (C) 2014 by authors and Scientific Research Publishing Inc.

This work is licensed under the Creative Commons Attribution International License (CC BY). http://creativecommons.org/licenses/by/4.0/

\section{Open Access}

\section{Abstract}

This study assessed the knowledge, and perceptions on safety measure practices and challenges of private sector participation (PSP) operators on solid waste management in Lagos State, Nigeria. This was a cross-sectional study and utilized interviewer administered questionnaire. The study employed purposive sampling among 256 PSP operators. Data were analyzed using descriptive statistics, Pearson's product moment and multiple regression analysis correlation at $5 \%$ level of significance. Respondents' age was $35.7 \pm 4.2$ years, and included $78.5 \%$ male. About $55.9 \%$ of the respondents spent up to 5 years in the waste management operations. Some $44.9 \%$ had at least completed secondary school education. A good knowledge of waste management was exhibited by $68.4 \%$ of the respondents. The respondents who had spent 16 years and above in waste management operations were more knowledgeable $(8.0 \pm 2.1)$ compared to those who had spent lesser time $(p<0.05)$. Knowledge on three diseases transmitted through unhygienic management of waste was reported as cholera $(21.6 \%)$, malaria $(17.7 \%)$ and typhoid $(12.8 \%)$. A positive correlation $(r=0.991, p<0.05)$ existed between respondents' age and the number of years spent on the waste management. Majority of the operators $(68.4 \%)$ had a good knowledge of waste management but still a great proportion were not using Personal Protective Equipment (PPE) like nose masks or hand gloves during operations. Enlightenment programmes such as seminars and workshops on waste management were found necessary and welcomed by the respondents. The major challenges faced by the PSP operators for their effective performance were negative attitude of waste generators towards them, lack of good road network and constant traffic congestion, reluctance of prompt payment of the fee and inadequate landfill sites and inaccessibility to the existing land fills during rainy season.

\footnotetext{
${ }^{*}$ Corresponding author.
} 


\section{Keywords}

\section{PSP; Waste Management; Waste Operators; Safety; KAP}

\section{Introduction}

Solid wastes are non-liquid and nongaseous products of human activities, which are regarded as being useless. They may be referred as refuse, garbage and sludge [1]. Solid Waste Management (SWM) constitutes one of the most crucial health and environmental challenges facing urban authorities of Sub Saharan Africa. This is because even though these urban governments use 20 - 50 percent of their annual budgets on SWM, only 20 - 80 percent of solid waste is collected and in Nigeria it is still less. The uncollected or illegally dumped wastes end up in open dumps and water bodies, leading to the contamination of surface and ground water and this constitutes human health and environmental concern [2] [3]. Cities in Nigeria, are among the fast growing cities in the world with associated urban waste problems such as littering and blockage of roads [4] [5].

Proper waste management will result in the abatement or reduction of pollution. Akinwale [6] posited that waste increased in a geometrical progression whereas collection and disposal was at an arithmetical progression. There is no dearth for legislative framework for waste management in Nigeria [7] [8]. In Nigeria solid waste management remains one of the greatest challenges facing state government environmental protection agencies and local government councils. The focus therefore has been on the technical aspects of different means of collection and disposal. Currently, attention is being focused on enhancing institutional arrangement to service delivery, with a special emphasis on privatization [9]-[11]. This has made the Federal Government instituted National Integrated Municipal Solid Waste Management Intervention Programme in seven cities of Nigeria which included Maiduguri, Kano, Kaduna, Onitsha, Uyo, Sango-Ota, and Lagos. However, Lagos state government established municipal solid waste management policy to encompass private sector participation in waste collection and transfer to designated landfill sites. Private sector participation operators had experienced a series of transformation not only in nomenclature but also in the design of their operations within the city. These were consequences of change in authority in the helms of affair within the last two decades [12] [13].

Unfortunately, cooperation from households, their willingness and ability to pay for services which are fundamental to the success of PSP operations posed a greater challenge. Since house-to-house waste collection method is adopted within the metropolitan, access to large proportion of houses in the city is not wide enough for service trucks while most of the access roads are not accessible particularly during much of the six-month rainy season in Lagos area [13]. In addition, operation of the PSP had been marred with inadequate equipment and machinery coupled with unavailability of spare part for the repair or maintenance of the old and inefficient trucks that are available for the operators. Although studies have documented solid waste generation pattern, characteristics and management in Nigeria, the knowledge and challenges of private sector operators about solid waste management had not been adequately assessed as the PSP is an emerging trend in various states in Nigeria [14]. Thus, this study aimed at assessing the knowledge, safety measure practices and challenges of private sector operators on solid waste management in Lagos State, Nigeria.

\section{Methods}

\subsection{Study Location and Design}

This was a cross-sectional study and utilized survey method with interviewer/self administered questionnaire. The interview was carried out among 256 PSP operators in Lagos state. The study employed purposive sampling as the selection of respondents was based on several eligible criteria. The inclusion criteria entailed being a PSP operator either as the proprietor of the company, the manager or a worker who is the most senior and knowledgeable among the staff members.

Lagos state, one of the six states which constituted south-west zone in Nigeria (Nigeria has 36 States and one Federal Capital Territory and the population is over 167 million), is the commercial and former political capital of the nation. It is classified as one of the mega cities in Africa which is located in South Western Nigeria on the west coast of Africa, within latitudes $6^{\circ} 23^{\prime} \mathrm{N}$ and $6^{\circ} 41^{\prime} \mathrm{N}$ and longitudes $2^{\circ} 42^{\prime} \mathrm{E}$ and $3^{\circ} 42^{\prime} \mathrm{E}$. The city has 20 Local 
Government Authorities (LGAs) and 37 Local Development Authorities. Although Lagos state is the smallest state in term of land mass, with an area of 356,861 hectares of which 75,755 hectares are wetlands, yet it has the second highest population, which is over $5 \%$ of the national estimate. However, a parallel population count by the Lagos State government put the population at about 17 million which include both resident and floating population. Metropolitan Lagos covers a land area of $37 \%$ of the Lagos State and is home to over $85 \%$ of the state's population. The rate of population growth is about 275,000 persons per annum with a population density of 2594 persons per square $\mathrm{km}$. and by the year 2015 it will be among the ten most populous cities in the world [15] [16]. Lagos' share of Nigeria's GDP is 12\% valued at USD 29 Billion from USD 18 Billion in 2005. It has $80 \%$ of country's industrial/commercial activities, $45 \%$ of national electricity consumption and $50 \%$ of petroleum products consumption (Lagos State Vision 20:2020 First Implementation 2010-2013). With a modest generation of 1.1 million tons of waste in 1991, the projection climbed up to about 1.8 million tons in 1998 and 4.4 million tons in the year 2010 [13].

\subsection{Study Population}

To date, there are 624 registered PSP operators within Lagos state [13]. The PSP operators had local government/Community level union/association that regulate the activities of their members and set standards of practice. There are no specialized training programmes for these operators other than learning as apprentices on the job while capital remains the major factor determining how and when the operations will commence. They are under an organized Association which controls their operations welfare. Each of the PSP operator reaches agreement with the apprentice to determine the length of their training. PSP operator must register the trade name of the company with the State Waste Management Regulatory Agency before they commence operation. The study population consisted of the proprietor of the company, the manager or a worker who is the most senior among the staff found on site. Two hundred and fifty-six (256) PSP operator companies were visited through proper introduction and protocols. Alternative visits were made when the respondents were busy or not available. The researchers worked through the unions to earn support. The leaders of each association gave the address released the addresses and directions of their members' offices. In addition, association leaders encouraged all members to provide support for the study and explained that the interviewer/investigators were not government tax collectors and that the study will not cause any risk to their operations. The researchers explained the study objectives to the participants. Anonymity and confidentially were assured, signed individual consents were obtained to undertake the interview. A set of semi-structured questionnaire was developed to elicit information such as PSP operators' demographic and socio-cultural characteristics. A 15-point scale was developed and used to gather information on knowledge about waste management, diseases associated with unhygienic handling of waste, the safety practices and the challenges faced by the operators. Interviews were conducted by six trained research assistants (3 each of male and female) who are university graduates and were acquainted with questionnaire research. They were trained in how to use the instrument and how they should introduce themselves and the research objectives modestly to the PSP operators during the interview.

\subsection{Data Analysis}

Data generated from the field were edited daily. Then they were coded and entered into the computer for analyses using the SPSS Windows Version 18 (Chicago, IL). Data were presented as mean standard deviation for continuous variables and percentages for categorical variables. Pearson's product moment correlation coefficients were computed to determine the associations between continuous variables. Stepwise multivariate linear regression analysis was performed to identify variables that predict the knowledge indicators. Statistical significance was defined at $\mathrm{p}<0.05$.

\section{Results and Discussion}

\subsection{Demographic Profile of the Participants}

Participants' characteristics are presented in Table 1. The mean age which ranged from 27 - 60 years was $35.7 \pm$ 4.2 years. There were 201 (78.5\%) male and 55 (21.5\%) females. More than half (55.9\%) had spent 5 years and below in the waste management operation with (44.9\%) had at least completed secondary school education. As shown in Figure 1, the three major reported diseases which are transmitted through unhygienic management of 
Table 1. Demographic profile of the participants $(\mathrm{N}=256)$.

\begin{tabular}{ccc} 
Characteristics & Number & $\%$ \\
Age & 256 & \\
Mean $\pm \mathrm{SD}=35.7 \pm 4.2$ years & & \\
(Min. - Max. $=27-60$ years) & & \\
Sex & 201 & 78.5 \\
Male & 55 & 21.5 \\
Female & & \\
Education & 28 & 10.9 \\
Completed Primary School & 115 & 44.9 \\
Completed Secondary school & 113 & 45.2 \\
Tertiary education & & \\
Years in operation range & 143 & 10.2 \\
$\leq 5$ & 83 & 1.6 \\
6 - 10 & 26 & 32.3 \\
11 - 15 & 4 & \\
$\geq 16$ & & \\
\hline
\end{tabular}

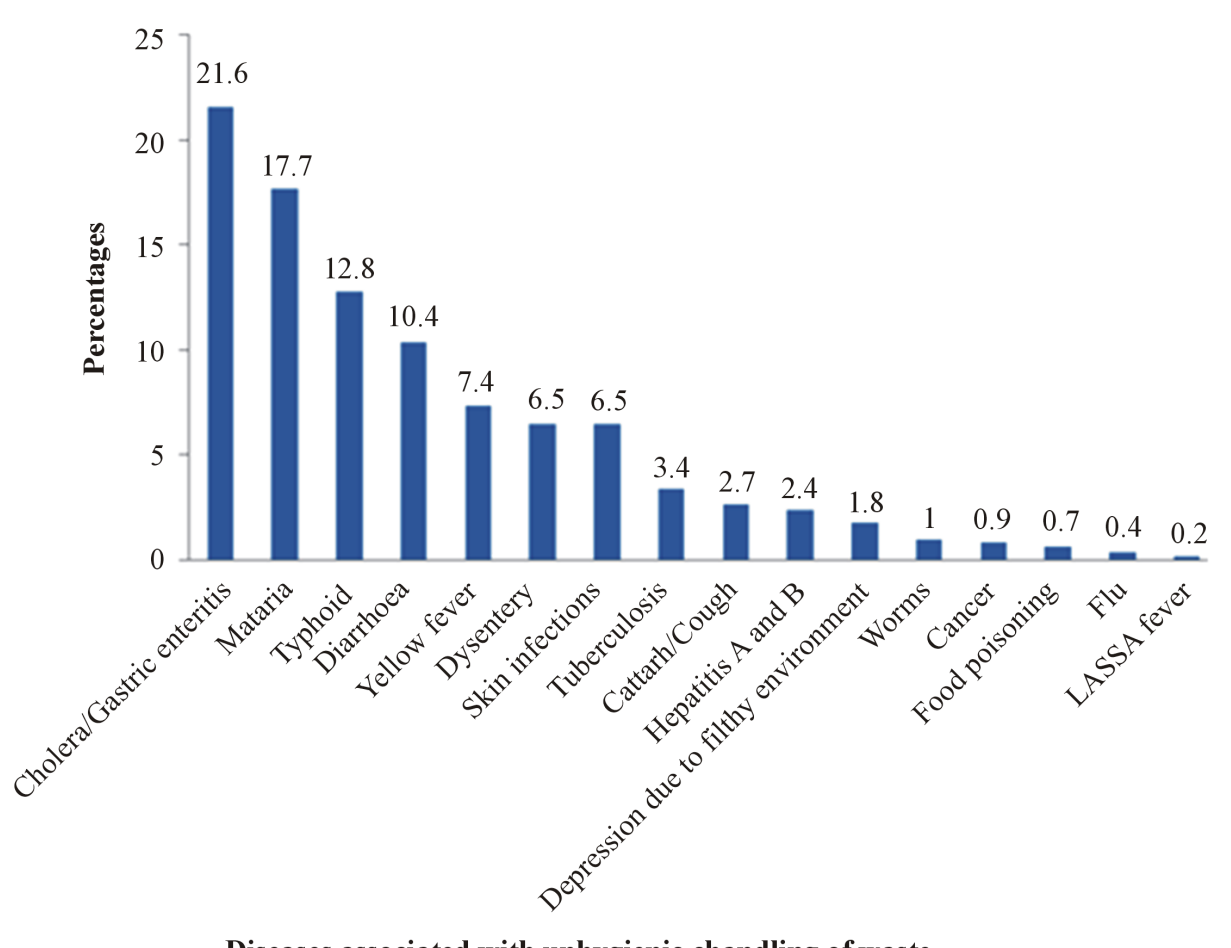

Diseases associated with unhygienic chandling of waste

\section{Figure 1. Disease perceptions of their work.}

waste were cholera (21.6\%), malaria (17.7\%) and typhoid (12.8\%). Other diseases mentioned which are of public health concerns were diarrhoea (10.4\%), hepatitis A and B (2.4\%), tuberculosis (3.4\%), cancer (0.9\%) and Lassa fever (0.2\%). 


\subsection{PSP Operators' Knowledge on Solid Waste Management}

During the interview, information about the respondents' knowledge on waste management was collected. Respondents mean knowledge score was $7.5 \pm 2.8$ and $68.4 \%$ had good knowledge on solid waste management. Knowledge of waste management was compared with four respondents' characteristics (Table 2). Respondents' age group did not show any significant difference in their average knowledge score likewise the gender and respondents level of education. PSP operators who had spent 16 years and above in waste operations were more knowledgeable $(8.0 \pm 2.1)$ compared to those who had spent 11 - 15 years, 6 - 10 years and $\leq 5$ years in operation $(t=4.270, p=0.006)$. As shown in Table 3 , there was a positive correlation between respondents age and the number of years spent on the waste operation $(r=0.991, p<0.01)$ indicating that older PSP operators had spent more time on operation compared to the younger operators. Knowledge on waste management was found to be positively related to the number of years spent in operation $(r=0.158, \mathrm{p}<0.05)$. These results suggested that subjects who had more knowledge of waste management had spent 16 years or more in operation. The perceived practice of respondents on the use of PPE was positively correlated with the knowledge on waste management ( $\mathrm{r}$ $=0.130, \mathrm{p}<0.05)$. On the other hand, there were no significant correlations between perceived practices of respondents on the use of PPE on age of the respondents and number of years in operation. These findings suggest that practice of respondents on the use of PPE on waste management may not be associated with age and number of years respondents had spent in operation.

\subsection{Safety Measure Practices and Challenges of PSP Operators during Operation}

Safety measure practices of the PSP operators during solid waste handling-collection, transportation and disposal were compared with their level of education and their knowledge of waste management. Table 4 shows that no significant association exist between Operators' level of education, knowledge of waste management and

Table 2. Factors associated with the knowledge about waste management $(\mathrm{N}=256)$.

\begin{tabular}{|c|c|c|c|c|c|}
\hline Characteristics & Number & $\overline{\mathrm{x}}$ & \pm SD (Knowledge about waste management) & $\mathrm{F} / \mathrm{t}$ test & p-value \\
\hline \multicolumn{6}{|l|}{ Age range (Years) } \\
\hline$\leq 30$ & 8 & & $6.5 \pm 2.1$ & & \\
\hline $31-40$ & 218 & & $7.4 \pm 2.9$ & 0.385 & 0.764 \\
\hline $41-50$ & 28 & & $7.7 \pm 3.0$ & & \\
\hline$\geq 51$ & 2 & & $7.5 \pm 3.5$ & & \\
\hline \multicolumn{6}{|l|}{ Sex } \\
\hline Male & 201 & & $7.4 \pm 3.0$ & 0.653 & 0.514 \\
\hline Female & 55 & & $7.7 \pm 2.4$ & & \\
\hline \multicolumn{6}{|l|}{ Education } \\
\hline Completed primary school & 28 & & $7.4 \pm 3.0$ & & \\
\hline Completed secondary school & 115 & & $7.2 \pm 2.9$ & 0.764 & 0.467 \\
\hline Tertiary education & 113 & & $7.7 \pm 2.7$ & & \\
\hline \multicolumn{6}{|l|}{ Years in operation } \\
\hline$\leq 5$ & 143 & & $7.9 \pm 2.7$ & 4.270 & 0.006 \\
\hline $6-10$ & 83 & & $6.5 \pm 2.8$ & & \\
\hline $11-15$ & 26 & & $7.7 \pm 3.1$ & & \\
\hline$\geq 16$ & 4 & & $8.0 \pm 2.1$ & & \\
\hline
\end{tabular}


Table 3. Correlation matrix of the predictor of knowledge on waste management and practices of PPE usage.

\begin{tabular}{|c|c|c|c|c|}
\hline Variables & $\begin{array}{l}\text { Respondent's age } \\
\text { in years }\end{array}$ & $\begin{array}{l}\text { Number of years } \\
\text { in operation }\end{array}$ & $\begin{array}{c}\text { Knowledge on } \\
\text { waste management }\end{array}$ & $\begin{array}{l}\text { Practice of personal } \\
\text { protective equipment }\end{array}$ \\
\hline Respondent's age in years & 1 & & & \\
\hline Number of years in operation & $0.991^{* *}$ & 1 & & \\
\hline Knowledge on waste management & 0.141 & $0.158^{*}$ & 1 & \\
\hline Practice of PPE & -0.147 & -0.034 & $0.130^{*}$ & 1 \\
\hline
\end{tabular}

${ }^{* *}$ Correlation is significant at the 0.01 level (2-tailed); ${ }^{*}$ Correlation is significant at the 0.05 level (2-tailed).

Table 4. PSP operators' characteristics associated with safety measure practices during waste handling.

\begin{tabular}{|c|c|c|c|c|}
\hline \multirow[t]{2}{*}{ PSP Operators' characteristics } & \multicolumn{2}{|c|}{ Safety measure practices } & \multirow{2}{*}{ Total (\%) } & \multirow{2}{*}{$\chi^{2}$ p value } \\
\hline & Always use Hand gloves (\%) & Not always use Hand gloves (\%) & & \\
\hline \multicolumn{5}{|l|}{ Level of education } \\
\hline Primary & $14(10.2)$ & $14(11.8)$ & $28(10.9)$ & 0.679 \\
\hline Secondary & $65(47.4)$ & $50(42.0)$ & $115(44.9)$ & \\
\hline Tertiary & $58(42.3)$ & $55(46.2)$ & $113(44.1)$ & \\
\hline \multicolumn{5}{|l|}{ Knowledge of waste management } \\
\hline Poor knowledge & $45(32.8)$ & $36(30.3)$ & $81(31.6)$ & 0.656 \\
\hline Good knowledge & $92(67.2)$ & $83(69.7)$ & $175(68.4)$ & \\
\hline \multirow[t]{2}{*}{ Total } & 137 & 119 & 256 & \\
\hline & Always use nose mask (\%) & Not always use nose mask (\%) & & \\
\hline \multicolumn{5}{|l|}{ Level of education } \\
\hline Primary & $7(7.7)$ & $21(12.7)$ & $28(10.9)$ & 0.459 \\
\hline Secondary & $43(47.3)$ & $72(43.6)$ & $115(44.9)$ & \\
\hline Tertiary & $41(45.1)$ & $72(43.6)$ & $113(44.1)$ & \\
\hline \multicolumn{5}{|l|}{ Knowledge of waste management } \\
\hline Poor knowledge & $25(27.5)$ & $56(33.9)$ & $81(31.6)$ & 0.287 \\
\hline Good knowledge & $66(72.5)$ & $109(66.1)$ & $175(68.4)$ & \\
\hline Total & 91 & 165 & 256 & \\
\hline
\end{tabular}

whether they always use hand gloves during operation. However, 64.5\% of the PSP operators did not always use nose mask during operations. Use of nose mask during operation did neither significantly associated with their level of education nor their knowledge of waste management. The major challenges of the PS operators during waste management operations (Table 5) were appalling attitude of waste generators to waste management personnel (21.9\%); lack of good road network and constant traffic congestion (21.1\%); waste generators are not willing to pay for the services they received (10.9\%) and inadequate landfill site and inaccessibility to the existing land fill particularly during rainy season (9.8\%). In addition, inadequate equipment/tools to work with e.g. trucks (7.8\%); inadequate funds to develop waste management industry (7.4\%); lack of good road network and constant traffic congestion (2.7\%) and lack of technical know-how on the part of PSP operators (2.3\%) were reported by the PSP operators.

The study assessed the knowledge, safety measure practices and challenges of private sector participation operators on solid waste management in Lagos State, Nigeria. It was found that high proportion of the operators 
Table 5. Challenges faced by PSP operators on waste management.

\begin{tabular}{|c|c|c|}
\hline Challenges & Number & $\%$ \\
\hline Appalling attitude of waste generators to waste management Personnel & 56 & 21.9 \\
\hline Inadequate landfill site and inaccessibility to the existing land fill during raining season & 25 & 9.8 \\
\hline Lack of manpower to service operations in the sector & 4 & 1.6 \\
\hline Inadequate equipment/tools to work with e.g. trucks & 20 & 7.8 \\
\hline Lack of technical know-how on the part of PSP operators & 6 & 2.3 \\
\hline Inadequate finances to develop waste management industry & 19 & 7.4 \\
\hline Lack of good road network and constant traffic congestion & 61 & 23.8 \\
\hline The waste generators are not willing to pay for the services rendered to them & 28 & 10.9 \\
\hline Cart pushers/illegal waste management operators menace & 2 & 0.8 \\
\hline High cost of equipment maintenance & 2 & 0.8 \\
\hline Instability in policy formulation about waste management & 3 & 1.2 \\
\hline No response & 30 & 11.7 \\
\hline Total & 256 & 100 \\
\hline
\end{tabular}

were within the age range of 31 - 40 years while majority were male. This is an implication that the study population is more independent and within the active/working age group. Likewise, more male respondents suggested that the operation of PSP is energy sapping (physical stress) which only men will be able to cope because of their natural endowment.

More than half of the respondents had spent 5 years and below in the operation. In a related study among PSP operators in Agege Local government area of Lagos State, Idowu et al., [17] reported that all the PSP operators interviewed have been in business for periods not less than 10 years. About $44.9 \%$ had at least completed secondary school education. This showed that operation of the PSP — the collection, transportation and disposal of solid waste does not strictly required higher level of education and those who had completed secondary school education and below could work efficiently during operation.

Ogbalu [18] observed in his study that a number of health hazards in Nigerian cities such as dysentery, typhoid, cholera, etc have been associated with poor solid waste management. In Sokoto yellow fever epidemic during 1980s was traced to uncleared refuse dumps resulting from a strike from the waste handlers (Sridhar, personal communication). This study revealed that the PSP operators reported cholera (possibly gastro-enteritis) as the most transmitted diseases through unhygienic management of waste while malaria, typhoid, diarrhea, hepatitis A and B, tuberculosis, cancer and Lassa fever were also mentioned. This affirmed that unhygienic handling of solid waste by the operators could result into contacting any of the above mentioned diseases. Knowledge of waste management is an important factor for safe and effective/efficient services among the operators. In this study, high proportion of the operators had good knowledge of waste management.

Knowledge about anything is based on the quality and quantity of information received about the matter and the channel of communication. This study observed that respondents' gender and level of education did not significantly associate with knowledge of waste management. Invariably, this indicated that gender and educational level of the PSP operators had no influence on their knowledge of waste management. However, number of years spent by the respondents in waste management operations significantly determined the knowledge of operators on waste management in the study area. This is a consequence of quality and quantity of information and skills acquired by the operators in their chosen trade. Further, this study documents that respondents age related positively with the number of years PSP operators spent on their job, indicating that older PSP operators had spent more time on operations compared to their younger counterparts. Also, respondents' knowledge on waste management was found to be positively related to the respondents number of years spent in operations. These findings suggested that subjects who had more knowledge of waste management had spent more number of years in waste management operation. 
The study found that safety measure practices of the PSP operators during solid waste handling-collection, transportation and disposal were not influenced by the operators' level of education, knowledge of waste management and whether they always use hand gloves during operation. While the proportion of the PSP operators who did not always use nose mask during operation appeared high in number (64.5\%), the use of nose mask during operation did neither significantly associated with their level of education nor their knowledge of waste management. This is an indication that use of nose mask during operation by PSP operators was not determined by their level of education nor their knowledge of waste management. Several challenges to the operation of PSP were highlighted during the survey and the major challenges were negative attitude of waste generators to waste management personnel, lack of good road network and constant traffic congestion and waste generators are not willing to pay for the services rendered to them. This corroborated the findings of Idowu et al., [15] in 2011 where it was established that delay in payment of service charge, inadequate enforcement for defaulters, irregular payment by the people and low pay for the services by government are some factors affecting PSP operators' performance. It was also found that inadequate landfill site area, inaccessibility to the existing land fill during rainy season and inadequate equipment/tools to work with (e.g. truck) hindered the smooth operations of PSP in the study area.

\section{Conclusion}

This study revealed that majority of the operators had a good knowledge of waste management, gender and level of education had no influence on PSP knowledge of solid waste management but years spent in operations determined the knowledge of operators on waste management in the study area. Cholera/gastroenteritis was found to be the most perceived diseases transmitted through unhygienic handling of solid waste while high proportion of the PSP operators did not always use nose mask during operation. Appalling attitude of waste generators to waste management personnel, lack of good road network and constant traffic congestion and waste generator are not willing to pay for the service we rendered to them, which were the major challenges to operation of PSP. There is a need to address these challenges in order to make PSP operated waste management business viable.

\section{Acknowledgements}

The authors acknowledge the contributions made by Dr A. Onobokun, Centre for African Settlement Studies and Development (CASSAD), Ayo Adekunle Close, Bodija, Ibadan, Nigeria.

\section{References}

[1] Leton, T.G. and Omotosho, O. (2004) Landfill Operations in the Niger Delta Region of Nigeria. Engineering Geology, 73, 171-177.

[2] Achankeng, E. (2003) Globalization, Urbanization and Municipal Solid Waste Management in Africa, African Studies Association of Australasia and the Pacific. Conference-Proceedings, African on a Global Stage.

[3] Mugagga, F. (2006) The Public-Private Sector Approach to Municipal Solid Waste Management: How Does It Work in Makindye Division, Kampala District, Uganda? MPhil. Thesis, NTNU, Trondheim.

[4] Onibokun, A.G. and Kumuyi, A.J. (1996) Urban Poverty in Nigeria: Towards Sustainable Strategies for Its Alleviation. Centre for African Settlement Studies and Development, Ibadan, 12.

[5] Geoffrey, I.N. (2005) The Urban Informal Sector in Nigeria: Towards Economic Development, Environmental Health, and Social Harmony. Global Urban Development Magazine, 1. http://www.globalurban.org/Issue1PIMag05/MagHome.htm

[6] Akinwale, A. (2005) Waste Management in Nigeria Local Governments. International Conference on Energy, Environment and Disasters 2005, Charlotte, 24-30 July 2005, 24-30.

[7] Atsegbua, L.A. (2003) Environmental Law in Nigeria. Theory and Practice, Lagos, 102-103.

[8] Ahmed, S.A. and Ali, M. (2006) People as Partners: Facilitating People’s Participation in Public-Private Partnerships for Solid Waste Management'. Habitat International, 30, 781-796. http://dx.doi.org/10.1016/j.habitatint.2005.09.004

[9] World Bank (1992) World Development Report. Development and Environment, New York.

[10] Cointreau-Levine, S. (1994) Private Sector Participation in Municipal Solid Waste Management Service in Developing Countries. The Formal Sector-UNDP/UNCHS/The World Bank-Urban Management Programme, $52 \mathrm{p}$.

[11] Adedipe, N.A., Sridhar, M.K.C., Baker, J., Verma, M., Faruqui, N. and Wagner, A. (2005) Waste Management, 
Processing, and Detoxification. In: Chopra, K., Leemans, R., Kumar, P. and Simons, H. Eds., Ecosystems and Human Well-Being: Policy Responses, Vol. 3, Oisland Press, Washington, 313-334.

[12] Ogwueleka, T.C. (2009) Municipal Solid Waste Characteristics and Management in Nigeria. Iranian Journal of Environmental Health Science \& Engineering, 6, 173-180.

[13] Adepitan, A.O. (2010) Waste Management Practice in Nigeria (Lagos State Model 1999-2009). JIMSIF Limited, Lagos, 1-98.

[14] Sridhar Mynepalli, K.C. (2005) Private Sector Participation in Water and Waste Management Services: A Nigerian Perspective. Journal of Environmental Health, Nigeria, 2, 75-85.

[15] United Nation's Report (2001) Urbanisation Patterns and Rural Population Growth at the Country Level. United Nations Population Division, World Population Prospect.

[16] National Bureau of Statistics (2007) Nigeria Provisional Result of the 2006 Population Census. www.nigerianstat.gov.ng/Connections/Pop2006.pdf

[17] Idowu, O.B.A., Omirin, M.M. and Osagie, J.U. (2011) Outsourcing for Sustainable Waste Disposal in Lagos Metropolis: Case Study of Agege Local Government, Lagos. Journal of Sustainable Development, 4, 116-131.

[18] Ogbalu, A.I. (2004) Refuse Management: The Role of Health Education. Environmental Studies and Research Journal, 4, 41-53. 